\title{
The Survival of Cultural Institutions in Post-apartheid South Africa: A Case of Bakoni Malapa Open Air Museum
}

\section{Dan Musinguzi}

Stenden University Qatar, Al-Jeleait Street, Bin Omran, P.O. Box 36037, Doha, Qatar

Email: DMusinguzi@stenden.edu.qa

Israel Kibirige

School of Education, Discipline of Maths, Science \& Technology Education, Turfloop Campus, University of Limpopo, Private Bag X1106, Sovenga, 0727, South Africa

Email: Israel.Kibirige@ul.ac.za

\section{Doi:10.5901/mjss.2014.v5n23p1669}

\begin{abstract}
Globally, the role played by cultural institutions such as museums cannot be underestimated. The roles of museums as centres of cultural heritage education/ preservation, entertainment, relaxation and research significantly contribute to the development of societies and their cultural heritage identities. However, such roles are lost if museums fail to survive the challenges that threaten their existence. Surprisingly, there has been no communication about the survival strategies of open air museums, specifically on the African continent. This short communication advances understanding on cultural heritage by reporting on the survival strategies employed by Bakoni Malapa Open Air Museum in post-apartheid South Africa.
\end{abstract}

Keywords: Strategies, Challenges, Heritage, Preserve

\section{Introduction}

\subsection{Background}

The survival of cultural institutions specifically museums is of great concern among museum practitioners, researchers, and the general public. This is because "most countries have recognized the importance of museums as places for the preservation, study, and presentation of their cultural past" (United National Educational, Scientific and Cultural Organization 2007). If museums fail to survive the challenges, their role in society ceases and as a consequence the invaluable cultural heritage information and assets are likely to be lost. In order to minimize this loss, international organizations such as the International Committee for Museums (ICOM), United National Educational, Scientific and Cultural Organization (UNESCO) and International Council on Monuments and Sites (ICOMOS) have invested skills and resources in preserving areas of cultural heritage significance for the benefit of the present and future generations. Despite the efforts of these organizations, cultural heritage institutions like museums still face some of the following challenges.

First, since museums are non-profit making organizations (International Council of Museums 2004) most of them depend on public funding. The challenge is that public funding is dwindling and as a result, museums have been forced to become market-oriented (McPherson 2006 cited in Cole 2008:177). When museums became market-oriented, on the other hand, there is a danger of losing important themes that define their identity. Thus, it seems one problem creates another resulting into a complex situation that may need new strategies in order to survive in the competitive global market.

Second, seasonality causes considerable fluctuation in visitor numbers. Yet most museums generate their income by charging entrance fee to visitors. A decrease in visitor numbers may imply a decrease in museum revenue. It is important to note that seasonality is a challenge for the entire tourism industry of which the museum sector is part and parcel. In the same token, Kastenholz and de Almeida (2008:5) comment that "seasonality of demand is generally considered one of the major challenges within the tourism business, potentially jeopardizing its sustainable development."

Third, museums face a dilemma of preserving the cultural heritage of the past generations for the benefit of the present and future generations. Some community members of the present generation consider the cultural heritage 
items, used several years ago as out-dated and may demand for cultural heritage modifications that suit their preferences. Unless a museum has a strong and focused managerial team, it is likely to adopt cultural modifications that do not reflect its actual identity.

Fourth, attracting repeat visitors challenges most museums, especially those whose managers and employees underestimate the fact that "attracting repeat visitors is far more cost effective than constantly building new audiences" (Runyard and French 1999 cited in Cole 2008:180). In order to attract repeat visitors museums should offer new products and memorable experiences. Good visitor experience not only requires committed and focused management but also the efforts of all other employees of a museum. This implies that creating memorable experience requires the input of both museum management and the rest of the employees. However, with the skyrocketing cost of living amid low salaries, the relationship between management and employees may get sour (Musinguzi 2007:73-74) and it may become hard for them to work together for a common goal of creating good memorable experiences for museum visitors.

Fifth, Dawson (2008) argues that engaging the young generation in museum activities is a major challenge facing most museums today. He illustrates the argument by pointing out that although schoolchildren (the main segment of the young generation) visit museums, they are usually passive consumers. Dawson's (2008) argument may be valid because there is a cultural divide between the past and the contemporary societies. This divide is due to the fact that the young generation finds museum objects and stories of little relevance or at worst boring. Dawson (2008) further comments that: "certainly the demand from younger people has shifted strongly to only paying attention if content is truly entertaining". He cautions museums on the danger of losing the young generation by stating that: "unless you allow them to be active in engaging with the content, you will lose them" (Dawson 2008). Can museums package cultural heritage in a way that entertains the young generation without losing the cultural heritage themes that depict their identity?

\subsection{The Overview of Bakoni Malapa Open Air Museum}

Bakoni Malapa Open Air Museum is one of the South Africa's 300 museums. These include those of agriculture, geology, natural history, military, archaeology, arts, and mining (South Africa Arts and Culture Yearbook 2006/2007). Museums in South Africa are like those in other developing and developed economies in that they are purposely established to preserve the cultural heritage assets of societies. Globally, museums are grouped into two broad categories: non-open air and open air museums. An open air museum is described as "a number of buildings placed in an area set aside these buildings are shown as they were in the past" (UNESCO 1958:25). In South Africa, the open air museums are: the Tsonga Kraal, the South Sotho Museum, the Ndebele Museum, Kliptown and the Bakoni Malapa (South Africa Arts and Culture Yearbook 2006/2007). The Bakoni Malapa open air museum was established during the apartheid regime that started in 1948. The regime cherished the homeland system that was designed to enrich the minority whites at the expense of the vast majority of black South Africans and other races. The homelands consisted of Basotho Qwaqwa, Bophuthatswana, Ciskei, Gazankulu, KwaNdebele, KwaZulu, Swazi, Transkei, Venda, and Lebowa (Horrell 1973:4). Lebowa homeland is where the Bakoni people lived. In order to preserve their cultural heritage identity, Bakoni Malapa open air museum was established by the apartheid regime. Since the demise of the apartheid regime in 1994, no study has investigated the survival of this museum in a post-apartheid South Africa. This study aims to fill this existing knowledge gap by reporting on the survival strategies employed by the Bakoni Malapa Open Air Museum.

\section{Method}

This study adopted a descriptive research design and employed a qualitative method in collecting and analyzing data. Data were collected using personal observations and short interviews with the management and employees of Bakoni Malapa Open Air Museum. The collected data were analyzed using content analysis technique. The results are presented and briefly discussed in the ensuing section.

\section{Results and Discussion}

This section presents and also offers a short discussion on the survival strategies of Bakoni Malapa open air museum. The strategies include: overcoming seasonality, diversifying museum activities, attracting repeat visitors, engaging the young generation, and offering authentic cultural experience. 


\subsection{Overcoming Seasonality}

In order to survive the negative effects of seasonality, significant production of craftwork take places during low seasons, when there are few museum visitors and the employees have enough time to concentrate on craftwork (Musinguzi 2007:44). The crafts that the museum produces include: sleeping mats, floor mats, metal watering cans, metal kettles, grain baskets, animal hides, wood carvings, clay pots, calabashes, porridge stirrers, necklaces, cow dung pots, among others (Musinguzi 2007). These crafts are produced in large amounts and sold during peak seasons so as to generate income that tend to compensate for the limited revenue usually experienced in low seasons. Apart from being an alternative source of revenue, crafts play a significant role in marketing a destination by enriching visitors' experience (Musinguzi and Kibirige 2009:156). This is because "the purchase of handcrafts is an integral part of the tourism experience for international tourists. An attractive, authentic and good quality handcraft taken home from an enjoyable holiday has continuing power to evoke wonderful memories, and indeed to arouse the interest of others who see it and to encourage them to visit the destination" (World Tourism Organization 2006:1). In addition, it should be noted that national tourists also benefit in the purchase of handcrafts that enhance their memorable experience regarding their national cultural diversity (Musinguzi 2007:35).

\subsection{Diversifying Museum Activities}

The management of Bakoni Malapa realized that diversifying museum activities and sources of income was necessary in that if one source of income is negatively affected, the museum can continue surviving on alternative sources. The diversification of museum activities goes beyond the showcasing of its heritage cultural objects. For example, the museum offers a barbequing (braaing) facility and a conference hall. These facilities are hired by the general public to entertain themselves during recreational moments and in this way the museum generates substantial income for its survival. The authors argue that museums that do not diversify may become 'slaves' to government/ public funding and donations that usually take long to materialize, thereby resulting in financial difficulties that has a potential of crippling the operations of the museum. For example, the Sports Museum of America closed down because of financial difficulties (Sandomir 2009). Similarly, financial difficulties may force museums to lay off employees, as was the case with the Milwaukee Public Museum in the USA (Schultze 2007).

\subsection{Attracting Repeat Visitors}

Although attracting repeat visitors is a challenge to some museums, Bakoni Malapa has overcome this challenge by creating an authentic memorable experience through cultural demonstrations that depict the traditions of the Bakoni people. Such memorable experience attracts repeat visitors. In fact, attracting repeat visitors is more cost effective than attracting new visitors (Runyard and French 1999 cited in Cole 2008:180).

\subsection{Engaging the Young Generation}

Children are an asset for any nation because young people are the 'building blocks' for any future society (Jillian 1996). So, engaging children in museum activities is vital. In order to attract the young generation to engage in museum activities, Bakoni Malapa museum has recognized the fact that young people like hands-on activities. Therefore, young people are encouraged to participate in hands-on activities such as preparing crafts and local foods (Musinguzi and Kibirige 2009:154). In addition, Bakoni Malapa Bakoni Malapa charges the lowest entrance fee (R1.50 approximately US\$ 0.2) for children unlike most museums in South Africa. Low and yet affordable fees encourages a high turnover of children, especially schoolchildren. This may result in the museum earning more from young people than it was previously thought. It should be remembered that schools that visit the museum are multi-cultural in nature suggesting that Bakoni Malapa has overcome the cultural divide that characterized the apartheid regime. This means the museum is on the path to unite the people into 'a rainbow nation' that advocates for ubuntu- the slogan that promotes the treatment of all people with the highest dignity they deserve. In this regard, exposing the young generation to cultural issues different from theirs is yet another breakthrough for the museum.

\subsection{Offering Authentic Cultural Experience}

Bakoni Malapa museum has successfully managed to offer authentic (traditional) experiences to visitors through the use 
of cultural demonstrations that depict the way the Bakoni people live. Visitors are able to enjoy the traditional ways of how the Bakoni people used to prepare and store foods, dress and dance. Also, artefacts that are used in cultural demonstrations add value to visitors' cultural experience. The artefacts are listed in Table 1 below.

Table 1: The Artefacts Used for Cultural Demonstrations at the Museum

\begin{tabular}{|c|c|}
\hline English name & Northern Sotho name \\
\hline Floor mat & Sethêbê \\
\hline Skin-rug & Letata \\
\hline Bark string dress & Legabe \\
\hline A rear-apron & Masese \\
\hline Loin-cloth & Detsiba \\
\hline Knuckle-bone bags & Dithebele \\
\hline Compactor & Sekato \\
\hline Wooden drum & Moropa \\
\hline Bow and arrow & Mosebo \\
\hline A horn & Phalaphala \\
\hline Hide shield & Sehlako \\
\hline Wooden assegais & Marumo \\
\hline Knives & Dithipa \\
\hline
\end{tabular}

Source: Musinguzi (2007: 45-46)

Also, there are a host of intangible cultural heritages that add value to the visitor and the local communities. Thus, the authors argue that Bakoni Malapa open air museum has to a large extent survived the challenges that threaten the existence of most museums around the globe. However, there are a few recommendations that may help the museum to continue surviving in the post-apartheid South Africa.

\section{Recommendations}

In order to strengthen the survival of Bakoni Malapa Open Air Museum, some recommendations regarding membership schemes, online communications, volunteers and interns, and marketing strategies are suggested.

\subsection{Membership Schemes}

Bakoni Malapa museum should introduce the membership schemes as another source of income. Membership schemes have been implemented in others museums. For example, in the context of mining museums, Cole (2004) found that membership schemes in the United Kingdom are "a significant source of income for one-third of small mining museums" and that "membership subscriptions provide an income stream that museum practitioners neglect at their peril" (Runyard and French 1999 cited in Cole 2008:180). Cole (2008:179) highlights the importance of membership schemes by arguing that "encouraging visitors to become members involves giving them a sense of involvement with the museum, and rewarding their repeat attendance with the development of products and additional services that are of interest to them".

\subsection{Emails and Online Social Networks}

With the advancement in technology and the shift in communication channels, museums should not depend only on the traditional means of communication of ink and paper. Bakoni Malapa museum should include emails as one of the convenient modes of communication in the contemporary society. The use of emails may save trees that utilize carbon dioxide from the atmosphere and may ultimately contribute to the reduction of global warming. Apart from emails, there are others modes of communication that could be explored. These may include online social networks such as Twitter, Linkedln and Facebook. These networks are potential tools for posting museum's photos and also for networking with potential new and repeat visitors, thereby widening the museum's audience base. For example, a number of museums are already on Facebook (http://www.musesphere.com/Facebook/index.htm) and other social networks. The social networks play a significant role as the most popular media of communication in today's society, especially among the young people who are better educated and earn high income (Lo et al. 2011). If Bakoni Malapa embraces online social networks it is likely to reach a wide audience and benefit greatly from such audience. 


\subsection{Volunteers and Interns}

Volunteers and student interns are invaluable human resource in most institutions. When institutions use volunteers, they may substantially reduce the costs of operation. This is because volunteers and interns receive much lower income than their regular employee counterparts. Thus, the use of "committed volunteers can significantly expand the operational capacity of museum" (Cole 2008:179). At the sometime, interns and volunteers bring new and yet rare essential skills to host institutions. Therefore, it is recommended that Bakoni Malapa should consider the use of interns and volunteers to further enhance its survival in this century and beyond.

\subsection{Marketing Strategies}

Cultural heritage institutions may not survive today's competitive market without embracing cost effective marketing strategies (Musinguzi 2007). Although Bakoni Malapa museum has relied on networking with other museums like Irish House and Hugh Exton Photographic museum in Polokwane Municipality, it is of paramount importance that the museum should embrace more rigorous marketing strategies like the use of a website and social networks.

\section{Concluding Remarks}

For museums to continue serving societies, they should be able to survive the challenges that threaten them. The challenges are multidimensional in nature and require multidimensional strategies. This paper has highlighted that dependence on dwindling public funding, seasonality, preservation of the past cultural heritage, attracting repeat visitors and engaging the young people are some of the challenges facing most museums. Although these challenges may hinder the progress of museums around the globe, it is important to note that Bakoni Malapa open air museum appears to have successfully overcome them by employing the strategies as indicated in this paper. In order for Bakoni Malapa museum to continue gaining higher heights of survival, it is recommended that the museum should: introduce membership schemes use emails and social networks, use volunteers and interns, and embrace more marketing strategies.

\section{References}

Cole D (2004). Exploring the sustainability of mining heritage tourism. Journal of Sustainable Tourism, 12(6): 480-494.

Cole D. (2008). Museum marketing as a tool for survival and creativity: the mining museum perspective. Museum Management and Curatorship, 23(2): 177-192.

Dawson R. 2008. Thinking about the future of museums: fourteen key issues. Available at: <http://www.rossdawsonblog.com/weblog/ archieves/2008/05/thinking_about.html> (Accessed: 02: 04: 2010).

Horrell M. (1973). The African Homelands of South Africa' Johannesburg: South African Institute of Race Relations.

International Council of Museums (2004). The definition of the museum. ICOM News, 57(2): 1.

Jillian D. (1996). Children, culture and education. From: <http://www.eric.ed.gov/ERICDocs/data/ ericdocs2sql/content_storage_01/ 0000019b/80/14/da/14.pdf> (Accessed: 14: 03: 2009).

Kastenholz E. \& de Almeida L. (2008). Seasonality in rural tourism - the case of North Portugal. Tourism Review, 63(2): 5-15.

Lo I.S.T., McKercher B., Ada L, Cheung C \& Law R. (2011). Tourism and online photography. Tourism Management, 34 (2): $725-731$.

McPherson G. (2006). Public memories and private tastes: the shifting definitions of museums and their visitors in the UK. Museum Management and Curatorship, 21(1): 44-57.

Musinguzi D. (2007). Managing the Transition at Bakoni Malapa Open Air Museum. MAthesis, Unpublished, Johannesburg: University of the Witwatersrand.

Musinguzi D. \& Kibirige I. (2009). The role of cultural and heritage education at Bakoni Malapa Open Air Museum: demonstrations of cultural practices and craftwork techniques. International Journal of Intangible Heritage, 4: 152-158.

Runyard S., \& French Y. (1999). Marketing and Public Relations Handbook for Museums. Galleries and Heritage Attractions', Oxford: Altamira.

Sandomir R. (2009). Financial problems cause sports museum of America to close. Available at: <http://www.nytimes.com/2009/ 02/22/sports/22spmuseum.html? r=1> (Accessed 23: 06: 2010).

Schultze S. (2007). Museum explores bankruptcy protection. Available at: http://www.jsonline.com/news/milwaukee/29430559.html (Accessed 23: 06: 2010).

South Africa Arts and Culture Yearbook (2006/2007). Available at: <http://www.gcis.gov.za /docs/ publications/yearbook/2007/chapter5. pdf> (Accessed 11: 12: 2010).

United National Educational, Scientific and Cultural Organization (UNESCO) (1958) UNESCO Regional Seminar on the Educational Role of Museums. Rio de Janeiro, Brazil, 7-30 September 1958. Available at: http://unesdoc.unesco.org/images/0006/000644/ 064490E0.pdf> (Accessed: 20:09: 2007).

World Tourism Organization (2006). 'Specific Programme to Promote Tourism Development in Sub-Saharan Africa', Final Report, Regional conference on "Tourism and handicraft: Opportunities for development." Ouagdougou, Burkina Faso, 3-4 November 2006. 